\title{
Rescaling Smart Destinations - The Growing Importance of Smart Geospatial Services during and after COVID-19 Pandemic
}

\author{
Bojan Radojević $\mathrm{A}^{*}$, Lazar LazićA ${ }^{A}$, Marija CimbaljevićA \\ Received: August 17, 2020 | Revised: September 10, 2020 | Accepted: September 11, 2020 \\ doi: 10.5937/gp24-28009
}

\begin{abstract}
The COVID-19 pandemic has imposed numerous, lasting adverse effects on the global tourism industry. At the same time, it exposed the competitive advantages that existing smart tourism infrastructure could provide for addressing urgent health issues and providing meaningful smart services. This paper initially provides examples of smart geospatial services based on COVID-19 pandemic-related data, such as algorithms for measuring social distancing through CCTV and proximity contract tracing protocols and applications. Indeed, smart destinations, as an evolutionary step of smart cities, very quickly became a practical and research framework in various other disciplines, from leisure and service-oriented to technical and geospatial domains. However, various technologies employed and interests of different stockholders create a constant need for rescaling of smart data to facilitate their usability in providing optimized smart tourism services. One of the pressing concerns is the functional alignment of geospatial data with tourism-related data. Thus, we aim to pinpoint the growing importance of smart geospatial services, by pointing to the main downturn of the current smart destination issue with geospatial data resolutions, and, by building upon the relations of the geospatial layer of data with the tourism-specific layer. To this end, we pinpoint two further research directions - reinvestigating spatial and temporal resolution as a core of data smartness and the need for contextual (tourism-oriented) scaling of smart technology. This could be of keen interest in post-pandemic tourism, where smart geospatial services will be of pressing concern, but also it still an issue to be resolved in further smart destination development.
\end{abstract}

Keywords: smart tourism destination; smart tourism; service optimization; spatial optimization; COVID-19

\section{Introduction}

With a quick spread of COVID-19, the globalized world has suddenly faced an immediate threat of infection and high death rates. The horrifying images of people suffering from the disease and an unprecedented reaction and measures undertaken by the Chinese state shocked the world (Gössling et al., 2020). The sense of urgency in western societies, however, oc- curred a bit later, with media reports from northern Italy. These reports showed another layer of a threat the inability of one of the most advanced health systems in the world to cope with a problem of this scale when no vaccine or conventional treatment is available. The global audience was warned that social (physical) distancing and limited interactions with other

\footnotetext{
A University of Novi Sad, Faculty of Science; Department of Geography, Tourism and Hotel Management, Trg Dositeja Obradovića 3, 21000 Novi Sad, Serbia

* Corresponding author: Bojan Radojević; e-mail: bojrado@gmail.com
} 
people would be the best way to deal with the current situation. This triggered an active collaboration of all citizens, trying to protect themselves and others, transforming this disease into a common problem (Stankov et al., 2020). The travel and tourism industry, as one of the backbones of a globalized society, was the first to be hit by the COVID-19 pandemic, showing its well-known fragility to sudden changes in tourism flows (Dwyer et al., 2020).

In a time of a crisis created by COVID-19 pandemic, people, organizations, and states turned towards technology asking for support (Gretzel et al., 2020; Stankov \& Gretzel, 2020). There have been many voices stating the increased willingness of people and organizations to engage more with technology or to change the attitudes towards it and even to temporarily forget about its potential downturns, such as privacy concerns or health issues due to its prolonged use (Geist, 2020). During the recent epidemic, a huge amount of mobile data on calls and behavior on social networks, collected from millions of users, concerning on the grounds of privacy and data protection. Access to data from personal devices may be justified, but it must comply with the privacy policy and citizens must be aware of its importance (Tešić et al., 2020).

Most notably, technology has been used to connect isolated people and workers and to replace physical interactions. In tourism, as well as, in other domains, there have been numerous innovative examples of robots replacing medical workers, smartphone mobile applications used to track people and their contacts, or Big Data-driven models predicting the spread of the virus (Zeng et al., 2020). Tourism marketing has switched to some already existing and new virtual solutions to satisfy people's desire for travel, such as virtual museum tours and even a virtual reality concert in Helsinki that attracted over one million spectators (Chandler, 2020).

Despite the crisis, tourism can not occur just in virtual spaces, and many solutions have appeared to help in resolving the spatial issue of the current pandemic a physical distancing. Indeed, tourist information services and travel planning assistants appear to be heavily influenced by the post-pandemic environment. As more and more people avoid crowded places, the popularity of outdoor activities is increasing, but also soon, we can expect the acceleration of digital transformation and even greater application of digital solutions (OECD, 2020; Stankov \& Filimonau, 2019). As a consequence, even a new term of "non-contact tourism" emerged in South Korea, refereeing to novel travel trend that avoids crowded spaces and/or indoor activities, but prefers outdoor attractions and activities with plenty of space available (El-Assasy, 2020). The following table summarizes the most novel examples of using smart services within smart destinations. Interestingly, all services are heavily impacted by the geospatial perspective for mitigating the issue of physical distancing.

Many of those examples came from states and cities that have extensively developed and optimized their smart infrastructure, such as South Korea, Singapore, or interestingly, Helsinki, that, together with Lyon, was rewarded for the first edition of the European Capital of Smart Tourism competition in 2019. Thus, smart city infrastructure seems to be a competitive advantage in combating COVID-19. Indeed, an advanced smart city and smart destination, in particular, rely heavily on the spatial component, as most of the services offered are location-oriented, both from the perspective of users and service providers. Since smart tourism destinations are grounded in situation-based optimization between technol-

Table 1. Examples of new smart geospatial services that have emerged in response to the COVID-19 pandemic.

\begin{tabular}{|c|c|c|c|}
\hline Example & Description & Geospatial perspective & Sources \\
\hline $\begin{array}{l}\text { Newcastle Urban } \\
\text { Observatory, UK }\end{array}$ & $\begin{array}{l}\text { Algorithms for measuring social } \\
\text { distancing through CCTV and } \\
\text { machine learning }\end{array}$ & $\begin{array}{l}\text { - CCTV enabled for face recognition } \\
\text { - Geospatial machine learning algorithms } \\
\text { - Issues with privacy }\end{array}$ & (Das \& James, 2020) \\
\hline $\begin{array}{l}\text { Government } \\
\text { Technology Agency, } \\
\text { Singapore }\end{array}$ & $\begin{array}{l}\text { TraceTogether proximity contract } \\
\text { tracing application deployed to } \\
\text { the general public }\end{array}$ & $\begin{array}{l}\text { - Geospatial data with timestamps } \\
\text { - Issues with privacy }\end{array}$ & (Ahmed et al., 2020) \\
\hline $\begin{array}{l}\text { Ministry of Land, } \\
\text { Infrastructure, and } \\
\text { Transport (MOLIT), } \\
\text { South Korea }\end{array}$ & $\begin{array}{l}\text { COVID-19 Smart Management } \\
\text { System (SMS) }\end{array}$ & $\begin{array}{l}\text { - Integrated geospatial information } \\
\text { framework } \\
\text { - Thematic geospatial analysis } \\
\text { - Spatial statistics } \\
\text { - Geospatial dashboards }\end{array}$ & $\begin{array}{l}\text { (Lee \& Lee, 2020; } \\
\text { Franch-Pardo, et al., } \\
\text { 2020) }\end{array}$ \\
\hline $\begin{array}{l}\text { European } \\
\text { Commission }\end{array}$ & $\begin{array}{l}\text { Re-open EU, web platform } \\
\text { to support a safe relaunch of } \\
\text { traveling and tourism across } \\
\text { Europe }\end{array}$ & $\begin{array}{l}\text { - Real-time web platform } \\
\text { - Geospatial data tourist information } \\
\text { service }\end{array}$ & $\begin{array}{l}\text { (European Union, } \\
\text { 2020) }\end{array}$ \\
\hline $\begin{array}{l}\text { INRIA, France and } \\
\text { Fraunhofer, Germany }\end{array}$ & $\begin{array}{l}\text { ROBERT proximity contact tracing } \\
\text { app protocol for StopCovid app }\end{array}$ & $\begin{array}{l}\text { - Geospatial data with timestamps } \\
\text { - Issues with privacy }\end{array}$ & (Ahmed et al., 2020) \\
\hline
\end{tabular}


ogy and physical environment (Liberato et al., 2018a), they should have the ability to provide related realtime information, improve real-time information access (Gajdošik, 2019), generate context-awareness and real-time monitoring (Buhalis \& Amaranggana, 2015). This complex ecosystem of technologies and different actors generate transparency in the governance of real-time information, enhancing the competitiveness of a smart tourism destination (Koo et al., 2016; Hernandez-Martin et al., 2017; Lin, 2017).

However, despite the existence of smart technology infrastructure, its factual transferability to optimized geospatial services is the hard-to-reach goal for many smart cities. Most of the outputs of smart systems build on sensors feeds can be presented on a map, since the data is a sequence of records ordered by time, and the location of the sensor is known. Typically, a geospatially enabled software is equipped with the possibilities to handle that data, transform, analyze even in a real-time if needed. To make a functional GIS for a smart tourism destination, it is crucial to input quality data that are as much as seamless to cover the tourism process of interest for service optimization. Sensors embedded in tourist destinations should monitor the overall environment, as well as the behavior of tourists (Gajdošik, 2019). However, smart systems provide a plethora of discreet and continues data, that cover particular destination but a change of scale and more in-depth inspection will show that they are not as usable at a certain point of interest for tourism process (tourism context scaling), either data can not be measured at that location or time (spatial and temporal scaling). Although smart sensors play an increasing role in the acquisition of data to enable smart service optimization, the understanding of its spatial capabilities to facilitate the tourism process as they interfere and influence the tourism system has received only minimal attention. In essence, smart tourism destinations face a challenge of the lack of geospatial understanding, which is primarily related to the different spatial coverage of smart technologies. This implies the need to upgrade existing and developing new urban innovations where smart systems help strengthen social and physical infrastructure to improve the provision of tourism, public, and social services (González-Reverté, 2019).

This "geospatial flaw" could potentially limit the capacities of smart destinations to tailor their services in post-pandemic tourism, where more emphasis will be put on locations, both for the issues of health safety or for its traditional importance for the optimization of smart services for tourists. Indeed, with the advent of Tourism 4.0, there is a growing need for spatial optimization of smart tourism destinations. Combining smart tourism capabilities with spatial thinking, both within realms of conceptual modeling and practical endeavors, can lead to the potential quality of life improvement in the city (Sagl et al., 2015) and service optimization for smart tourism destination. To address this issue we pinpoint two further research directions, emphasizing the scaling problem of smart system coverage for further research and service optimization in smart tourism destinations.

\section{Further research directions}

\section{Reinvestigating spatial and temporal resolution as a core of data smartness}

Geospatial information is crucial to analyzing and quantifying the performance of smart cities and smart destinations, which is related to mobility, energy consumption, environmental pollution, or public health. Given that the smart environment is based on the merging of the physical world and the digital sphere through the Internet of Things and ambient intelligence (Femenia-Serra et al., 2019a), we can single out intelligence, connectivity, and interaction (Liberato et al. , 2018b) as an essential function of geospatial data in the context of smart tourism development.

Spatial and temporal data and the demand for it are at the center of understanding of planning, management, and environmental protection on a smart tourism destination, necessary to ensure a balance between residents, tourists, and destination management (Supak et al., 2015). In the immediate past, cities and tourism destinations have been able to improve their governance using geospatial technologies. Nevertheless, there is a long way to go to take full advantage of these technologies (Tao, 2013). The integration of smart geospatial technologies with informationcommunication technologies (ICT) and sensors refers to the location cloud. The ultimate goal of a spatiotemporal data collecting is to provide location-based services for various applications using location cloud and transforming all available geographic location information (Li et al., 2013). Spatial and temporal modeling is critical to risk and vulnerability prevention for smart cities (Roche, 2017) and smart tourism destinations. One of the more important challenges for the adoption of spatial autocorrelation in the analysis of tourism data is the specifics of spatial units for data aggregation (Stankov al., 2017).

The spatial and temporal resolution of smart technologies allows for finding acceptable solutions to optimize services for a tourism destination and to improve the experience of tourists until the time when sensors 
will become ubiquitous creating a full realistic destination model. In this case, tourism experience can be enhanced by implementing technology platforms that interconnect stakeholders, integrate inputs from different sources, and enable real-time dynamic information sharing (Femenia-Serra et al., 2019b). Such systems can enhance and facilitate decision-making and what is also important, increase business efficiency. However, the complexity of networked society requires accurate, reliable, and real data to help decision-makers in social and economic decision-making processes. If we look closely, we can certainly see that most of that data are spatially related (Gruen, 2013). The theory of spatial sciences and geography speaks of the concept of "places" used in digital spatiality and has a significant position in the concept of smart cities and smart tourism destinations. A smart tourism destination needs to be spatially enabled, in the way that spatial enablement refers to the "places" as a system to maintain space-time processes (Roche, 2014). Spatial-temporal optimization can lead to a change in service or quality of service in the short or long term. The smart city infrastructure is equipped with the ability to collect large amounts of data and most of that data has a spatial and temporal dimension (Roche, 2017), while all of this data can also be used for smart tourism destination services optimization and higher competitiveness (Cimbaljević et al., 2018). Geo-referencing and spatiotemporal quantifying are required by almost every element of a smart city (Li et al., 2013) and smart tourism destination. For the tourism destination, it is essential to provide integrated service, but also to be proactive to prevent the problems of providing real-time information, and to anticipate the needs of tourists. Therefore, service optimization should be based on a functionally-pragmatic principle. More specifically, it should be striving for urban-technological planning (Sigalat-Signes et al., 2019), so that smart systems can capture, analyze and interpret information in real-time (Lopez de Avila, 2015), but in the way that technological improvements and urbanism are given equal attention, as well as to focus on tourist offer. In the case of smart destinations, service optimization is of particular importance to collect tourism data and those left by tourists while visiting a place to provide services in real-time (Hjalager, 2015). On the other side, it is also vital for optimized strategic management that will help stakeholders to improve the tourist experience at the destination (Polese et al., 2018).

\section{The need for contextual (tourism-oriented)} scaling of smart technology

Smart technologies are becoming ubiquitous. Increasing number of consumers live in smart cities and travel to smart tourism destinations. The spatially enabled society provides spatial information to cit- izens, tourists, businesses, and governments to maximize the quality of their activities (Williamson et al., 2010; Stankov et al., 2018). Stakeholder interconnection at a smart tourism destination creates a smart tourism ecosystem (Boes et al., 2016) in which everyone is connected from the citizens to the government. With the use of sensor-based technology, destinations collect and process large amounts of data. In this way, suppliers (organizations, businesses) can create value for individuals by providing optimized information that is processed based on the data collected (Kim \& Kim, 2017). Thus, tourism ecosystems become more open, emphasizing the importance of public-private cooperation, which enables coordination between entities. Further, if we consider the external and internal contexts, we can see that external or physical contexts are strongly related to the physical environment and are typically measured by physical sensors (Sagl et al., 2015). There are rare experimental cases of using body-mounted devices to directly measure tourists' emotions or to use big data analytics to derive tourists' emotional affection or sense of a place. However, typical smart city physical sensors cannot measure tourists' experience, so it is mostly ignored and neglected. For example, when receiving data collected from sensors related to air pollution, tourists may be misled to think that air is completely polluted in the broader area of the city, although that it is not a case in reality. Air pollution is usually monitored in areas that are often at risk, while sensors are rarely installed at non-hazardous locations. Data collected from sensors are very easily accessible publicly through mobile applications, but tourists are often not trained to interpret the available data, and thus all this can mislead tourists and

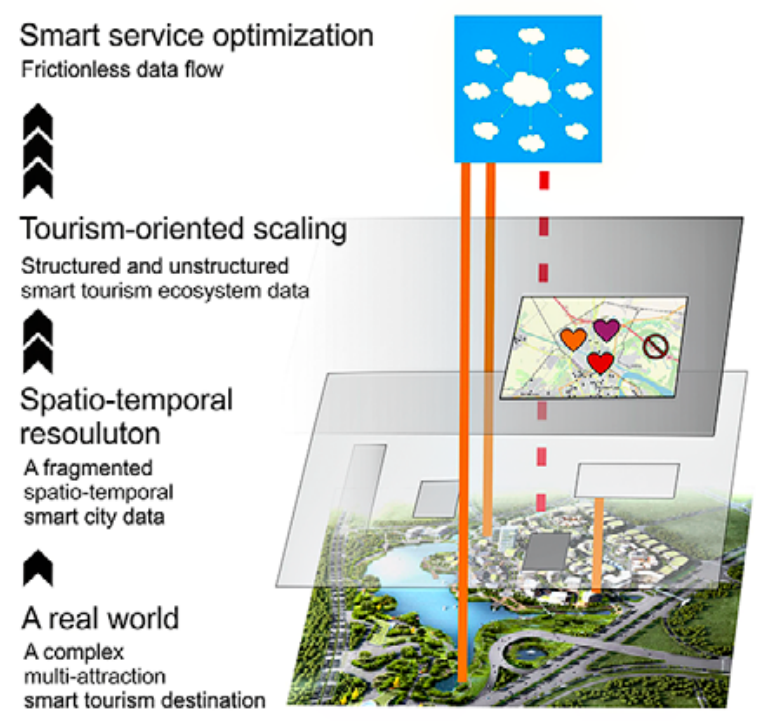

Figure 1. Essential layers of smart destinations for smart geospatial services 
direct them to make erroneous conclusions that can lead to tourists behavior change in the direction of giving up consumption, which eventually leads to a decrease in revenue at the destination. The need to scale and better integrate different spatial data with tourism data to enable location technologies that provide the basis for optimized smart geospatial services accelerates in the COVID-19 pandemic environment.

Taking all of the above into account, data collected from remote sensors through the smart infrastructure must be precisely processed using spatial scaling, time scaling, and contextually tourism-oriented scaling before presentation to tourists. Travelers need to judge the impact of the information used and learn to react with the whole situation in mind (Batty et al., 2012). To cope with the contemporary challenges of smart technologies, citizens and tourists need to become spatially literate (Roche et al., 2014).
The number of sensor technologies and sensor applications is rapidly increasing, but the distribution between sensors and applications is not uniform and proportional, so the broad capabilities of sensor technologies application remain limited (Sagl et al., 2015). Although the types of data collected through sensors and their smart applications remain the same, challenges in the future could be the development of selfmaintainable sensors and location and spatial information as a common good (Roche et al., 2014). Vast amounts of spatiotemporal referenced data collected through smart sensor infrastructure can be analyzed and transformed in real-time through cloud computing (Li et al., 2013), which will eventually support the managing of smart city and smart tourism destination. In this regard, data exchange is vital in tourism destinations through the technological platform that is supporting open data initiatives (Gajdošik, 2019).

\section{Concluding remarks}

A smart environment brought democratization in spatial data provision and sharing, allowing a variety of data types and sources, from administration and business to residents and travelers (Williamson et al., 2010). Almost all new technologies for smart cities and smart tourism destinations are geospatially enabled. A smart infrastructure collects a considerable amount of data that, by its quality and orientation, is not primarily tourism-oriented. Data collected from sensors in smart tourism destination can be used for smart services optimization and higher competitiveness. Analysis reveals that if the data collected by the sensors must first be subjected to contextual (tourismoriented) scaling before presenting to tourists. If the data collected by the sensor is presented to tourists without fine-tuning it can mislead tourists. There is a lack of data as for now because smart infrastructure cannot measure the experience of tourists.

Spatial and temporal modeling is crucial for smart tourism destinations management. Utilizing the spatial and temporal resolution of smart technologies enables us to find acceptable solutions to optimize the services of a smart tourism destination and to enhance the tourists' experience, in the direction of the connected experience. Therefore, successful spatial-temporal modeling requires ICT, geospatial, and sensors technology interconnectivity, cooperation, as well as knowledge sharing.

Finally, we can ask ourselves: can more sensors, more sensor applications, more sophisticated methods of data transformation, and the inclusion of contextual and spatiotemporal approaches lead for sure to improvement in services and competitiveness in the smart tourism destination in post-pandemic period? We can only hope that in the future, the full integration of various sensing technologies along with strategies for gathering and transforming data and contextual rescaling will help us to discover all the critical relationships and good and bad causalities that exist between tourists and fully sensor-equipped smart tourism destination.

The direction of further research could be the goal of building a conceptual model that would alleviate the problem of capturing and scaling all types of data collected through the smart city infrastructure in smart tourism destinations, which could be used to optimize services and increase competitiveness. Finally, if we know the scale of data collected through sensors infrastructure in smart tourism destination, future research in this area also could relate to the serious privacy concerns for residents and tourists within the smart tourism destination.

The COVID-19 pandemic accelerates the need to scale and better integrate different spatial data with tourism data to enable location technologies that provide the basis for optimized smart geospatial services in the post-pandemic era. Future research could focus on geospatially distributed tourism preferences in the environment after COVID-19. Spatial data science and location-based data may be more important than ever during this pandemic, and the question arises as to which COVID-19 spatial data are most important for tourism in destinations around the planet. Smart and spatial technologists have massive data collecting possibilities, and they must be used carefully, especially taking into account the challenge of privacy issues in which direction future research may also go. 


\section{References}

Ahmed, N., Michelin, R. A., Xue, W., Ruj, S., Malaney, R., Kanhere, S. S., Seneviratne, A., Hu, W., Janicke, H., \& Jha, S. (2020). A Survey of COVID-19 Contact Tracing Apps. IEEE Access, 8, 134577-134601. https://doi.org/10.1109/ACCESS.2020.3010226

Batty, M., Axhausen, K. W., Giannotti, F., Pozdnoukhov, A., Bazzani, A., Wachowicz, M., \& Portugali, Y. (2012). Smart cities of the future. European Physical Journal: Special Topics, 214 (1), 481-518. https://doi. org/10.1140/epjst/e2012-01703-3

Boes, K., Buhalis, D., \& Inversini, A. (2016). Smart tourism destinations: ecosystems for tourism destination competitiveness. International Journal of Tourism Cities, 2(2), 108-124. https://doi.org/10.1108/ IJTC-12-2015-0032

Buhalis, D., \& Amaranggana, A. (2015). Smart tourism destinations enhancing tourism experience through personalisation of services. In I. Tussyadiah \& A. Inversini (Eds.), Informationand Communication Technologies in Tourism (pp. 377-389). Lugano: Springer International Publishing.

Chandler, S. (2020). Virtual Reality Concert In Helsinki AttractsOver1MillionSpectators.Availableat:https:// www.forbes.com/sites/simonchandler/2020/05/05/ virtual-reality-concert-in-helsinki-attracts-over1-million-spectators/\#621fcdf61281 (o8 May 2020)

Cimbaljević, M., Stankov, U., \& Pavluković, V. (2019). Going beyond the traditional destination competitiveness-reflections on a smart destination in the current research. Current Issues in Tourism, 22(20), 2472-2477. https://doi.org/10.1080/13683500.2018.152 9149

Das, R., \& James, P. (2020). COVID-19: What can smart cities tell us about social distancing? | World Economic Forum. Available at: https://www.weforum.org/agenda/2020/04/smart-cities-technologycoronavirus-covid19/ (29 July 2020)

Dwyer, L., Peter, F., \& Dwyer, W. (2010). Tourism Economics and Policy. Bristol: Channel View Publications.

El-Assasy, A. (2020). How Does Korea Response to COVID-19? Sada El balad English 1. Available at: https://see.news/how-does-korea-response-to-covid-19-sada-elbadalad-englis/ (29 July 2020)

European Union (2020). Available at: https://ec.europa. eu/commission/presscorner/detail/en/ip 201045

Femenia-Serra, F., Neuhofer, B., \& Ivars-Baidal, J. A. (2019a). Towards a conceptualisation of smart tourists and their role within the smart destination scenario. The Service Industries Journal, 39(2), 109-133. https://doi.org/10.1080/02642069.2018.1508458

Femenia-Serra, F., Perles-Ribesb, J. F., \& Ivars-Baidala, J. A. (2019b). Smart destinations and tech-sav- vy millennial tourists: hype versus reality. Tourism Review, 74(1), 63-81. https://doi.org/10.1108/TR-022018-0018

Franch-Pardo, I., Napoletano, B. M., Rosete-Verges, F., \& Billa, L. (2020). Spatial analysis and GIS in the study of COVID-19. A review. Science of the Total Environment, 739, 140033. https://doi.org/10.1016/j. scitotenv.2020.140033

Gajdošík T. (2019). Big Data Analytics in Smart Tourism Destinations. A New Tool for Destination Management Organizations?. In: Katsoni V., Segarra-Oña M. (eds) Smart Tourism as a Driver for Culture and Sustainability. Springer Proceedings in Business and Economics. Cham: Springer. https:// doi.org/10.1007/978-3-030-03910-3 2

Geist, M. (2020). Opinion: After the tech-lash: new digital policy priorities in the post-pandemic world. Available at: https://www.theglobeandmail.com/ business/commentary/article-after-the-tech-lashnew-digital-policy-priorities-in-the-post/ (o6 May 2020)

González-Reverté, F. (2019). Building Sustainable Smart Destinations: An Approach Based on the Development of Spanish Smart Tourism Plans. Sustainability, 11, 6874, 1-24. https://doi.org/10.339o/ su11236874

Gössling, S., Scott, D., \& Hall, C. M. (2020). Pandemics, tourism and global change: a rapid assessment of COVID-19. Journal of Sustainable Tourism, 1-20. https://doi.org/10.1080/09669582.2020.1758708

Gretzel, U., Fuchs, M., Baggio, R., Hoepken, W., Law, R., Neidhardt, J., Pesonen, J., Zanker, M., \& Xiang, Z. (2020). e-Tourism beyond COVID-19: a call for transformative research. Information Technology and Tourism, 22(2), 187-203. https://doi.org/10.1007/ S40558-020-00181-3

Gruen, A. (2013). SMART cities: The need for spatial intelligence. Geo-Spatial Information Science, 16(1), 3-6. https://doi.org/10.1080/10095020.2013.772802

Hernandez-Martin, R., Rodriquez Rodriquez, Y., \& Gahr, D. (2017). Functional Zoning for Smart Destination Management. European Journal of Tourism Research, 17, 43-58.

Hjalager, A. M. (2015). 100 Innovations That Transformed Tourism. Journal of Travel Research, 54(1), 3-21. https://doi.org/10.1177/0047287513516390

Kim, D., \& Kim, S. (2017). The Role of Mobile Technology in Tourism: Patents, Articles, News, and Mobile Tour App Reviews. Sustainability, 9, 2082, 1-45. https://doi.org/10.3390/sug112082

Koo, C., Shin, S., Gretzel, U., Hunter, W. C., \& Chung, N. (2016). Conceptualization of Smart Tourism 
Destination Competitiveness. Asia Pacific Journal of Information System, 26(4), 367-384. http://dx.doi. org/10.14329/apjis.2016.26.4.367

Lee, D., \& Lee, J. (2020). Testing on the move: South Korea's rapid response to the COVID-19 pandemic. Transportation Research Interdisciplinary Perspectives, 5, 100111. https://doi.org/10.1016/j. trip.2020.100111

Li, D., Shan, J., Shao, Z., Zhou, X., \& Yao, Y. (2013). Geomatics for smart cities - concept, key techniques, and applications. Geo-Spatial Information Science, 16(1), 13-24. https://doi.org/10.1080/10095020.2013.7 72803

Liberato, P. M., Alén-González, E., \& Liberato, D. F. (2018a). Digital Technology in a Smart Tourist Destination: The Case of Porto. Journal of Urban Technology, 25(1), 75-97. https://doi.org/10.1080/10630732 .2017 .1413228

Liberato, P. M., Liberato, D. F., Abreu, A., AlénGonzález, E., \& Rocha, A. (2018b). Generation Y: The Competitiveness of the Tourism Sector Based on Digital Technology. In T. Antipova \& Á. Rocha (Eds.), Information Technology Science. MOSITS 2017. Advances in Intelligent System and Computing, 724, (pp. 227-240). Cham: Springer, https://doi. org/10.1007/978-3-319-74980-8 21

Lin, S. W. (2017). Identifying the critical success factors and an optimal solution for mobile technology adoption in travel agencies. International Journal of Tourism Research, 19(2), 127-144. https://doi. org/10.1002/jtr.2092

Lopez de Avila, A. (2015): Smart destinations: XXI century tourism. In ENTER2015 Conference on Information and Communication Technologies in Tourism, Lugano, Switzerland.

Masseno, M. D., \& Santos, C. (2019). Smart Tourısm Destınations Privacy Risks On Data Protection- A First Approach, From an European Perspective. Revista Eletrônica Sapere Aude, 1(1), 125-149-Autor Convidado. Retrieved from http://revistaeletronicasapereaude.emnuvens.com.br/sapere/article/view/27

OECD. (2020). Tourism Policy Responses to the coronavirus (COVID-19). Available at: https://www. oecd.org/coronavirus/policy-responses/tourism-policy-responses-to-the-coronavirus-covid19-6466aa2o/\#endnoteaoz56 (30 July 2020).

Polese, F., Botti, A. Grimaldi, M., Monda, A., \& Vesci, M. (2018). Social Innovation in Smart Tourism Ecosystems: How Technology and Institutions Shape Sustainable Value Co-Creation. Sustainability, 10, 140, 1-24. https://doi.org/10.3390/su10010140

Roche, S. (2014). Geographic Information Science I: Why does a smart city need to be spatially enabled? Progress in Human Geography, 38(5), 703-711. https://doi.org/10.1177/0309132513517365
Roche, S. (2017). Geographic information science III: Spatial thinking, interfaces and algorithmic urban places-Toward smart cities. Progress in Human Geography, 41(5), 657-666. https://doi. org/10.1177/0309132516650352

Sagl, G., Resch, B., \& Blaschke, T. (2015). Contextual sensing: Integrating contextual information with human and technical geo-sensor information for smart cities. Sensors, 15(7), 17013-17035. https://doi. org/10.3390/s150717013

Sigalat-Signes, E., Calvo-Palomares, R., Roig-Merino, R., \& Garcia-Adan, I. (2019). Transition towards a tourist innovation model: The smart tourismdestination Reality or territorial marketing? Journal of Innovation \& Knowledge, 1-9. https://doi. org/10.1016/j.jik.2019.06.002

Stankov, U., \& Filimonau, V. (2019). Reviving calm technology in the e-tourism context. Service Industries Journal, 39(5-6), 343-360. https://doi.org/10.10 $\underline{\text { 8o/02642069.2018.1544619 }}$

Stankov, U., \& Gretzel, U. (2020). Tourism 4.0 technologies and tourist experiences: a human-centered design perspective. Information Technology \& Tourism. https://doi.org/10.1007/s40558-020-00186

Stankov, U., Armenski, T., Klauco, M., Pavluković, V., Cimbaljević, M., \& Drakulić-Kovačević, N. (2017). Spatial autocorrelation analysis of tourist arrivals using municipal data: A Serbian example. Geographica Pannonica, 21(2), 106-114. https://doi. org/10.18421/GP21.02-04

Stankov, U., Filimonau, V., \& Vujičić, M. D. (2020). A mindful shift: an opportunity for mindfulnessdriven tourism in a post-pandemic world. Tourism Geographies, 1-10. https://doi.org/10.1080/14616688. 2020.1768432

Stankov, Uglješa, Jovanović, T., Pavluković, V., Kalinić, Č., Drakulić-Kovačević B, N., \& Cimbaljević, M. (2018). A regional survey of current practices on destination marketing organizations' Facebook Pages: the case of EU and. Geographica Pannonica, 22(2), 81-96. https://doi.org/10.5937/22-16673

Supak, S., Brothers, G., Bohnenstiehl, D. W., \& Devine, H. (2015). Geospatial analytics for federally managed tourism destinations and their demand markets. Journal of Destination Marketing and Management, 4(3), 173-186. https://doi.org/10.1016/j.jdmm.2015.05.002

Tao, W. (2013). Interdisciplinary urban GIS for smart cities: Advancements and opportunities. Geo-Spatial Information Science, 16(1), 25-34. https://doi.org $\lfloor 10.1080 / 10095020.2013 .774108$

Tešić, D., Blagojević, D., \& Lukić, A. (2020). Bringing "smart" into cities to fight pandemics: With the reference to the COVID-19. Zbornik Radova Departmana Za Geografiju, Turizam i Hotelijerstvo, 49(1), 99-112. https://doi.org/10.5937/zbdght2001099t 
Williamson I, Rajabifard A \& Holland P (2010). Spatially enabled society. Proceedings of the FIGURE Congress 2010, Facing the Challenges - Building the Capacity, Sydney. Available at: http://www.fig.net/ pub/fig2010/papers/invo3\%5Cinvo3 williamson rajabifard et al 4134.pdf
Zeng, Z., Chen, P.-J., \& Lew, A. A. (2020). From hightouch to high-tech: COVID-19 drives robotics adoption. Tourism Geographies, 1-11. https://doi.or g/10.1080/14616688.2020.1762118 